\title{
Effect of coating material (corn oil) on the storage life of persimmon fruit
}

Nabeel Alam ${ }^{1}$, Farzana Bibi ${ }^{1}$, Nadeem Khan ${ }^{1 *}$, Niaz Ahmad ${ }^{3}$, Awais $\mathrm{Khan}^{4}$, Bakht Taj Khan ${ }^{1}$, Javed Iqbal ${ }^{1}$, Ashfaq Ahmed ${ }^{1}$, Syed Asim Shah Bacha $^{1}$, Suliman Shah ${ }^{2}$ and Said Rawan ${ }^{1}$

1. Department of Horticulture, The University of Agriculture, Peshawar-KP-Pakistan

2. Department of Entomology, The University of Agriculture, Peshawar-KP-Pakistan

3. Department of Food Science, The University of Agriculture, Peshawar-KP-Pakistan

4. Department of Agronomy, The University of Agriculture, Peshawar-KP-Pakistan

*Corresponding author's email: nadeemaup@yahoo.com

Citation

Nabeel Alam, Farzana Bibi, Nadeem Khan, Niaz Ahmad, Awais Khan, Bakht Taj Khan, Javed Iqbal, Ashfaq Ahmed, Syed Asim Shah Bacha, Suliman Shah and Said Rawan. Effect of coating material (corn oil) on the storage life of persimmon fruit. Pure and Applied Biology. Vol. 6, Issue 1, pp363-368.

http://dx.doi.org/10.19045/bspab.2017.60035

\begin{tabular}{llll}
\hline \hline Received: $15 / 11 / 2016$ & Revised: $24 / 02 / 2017$ & Accepted: 28/02/2017 & Online First: 02/03/2017 \\
\hline
\end{tabular}

\section{Abstract}

An experiment was conducted to investigate "effect of coating material on the shelf life of persimmon (Diospyros kaki) at post-harvest laboratory, Department of Horticulture, The University of Agriculture Peshawar, during 2015. The experiment was laid out in Completely Randomize Design (CRD), repeated three times with two factors i.e. coating material (corn oil) and uncoated (control) and storage intervals (0,3,6,9,12,15 and18). Results showed that Results shows that corn oil increased fruit firmness $\left(2.51 \mathrm{Kg} / \mathrm{cm}^{2}\right)$, TSS $\left(20.92^{0} \mathrm{Brix}\right)$, lowest weight loss $(6.41 \%)$ and decay incidence (14.99\%).Storage duration showed the highest weight loss (15.65 $\%)$, decay incidence $(51.6 \%)$ and TSS $\left(24.48{ }^{0}\right.$ Brix $)$, lowest fruit firmness $\left(1.72 \mathrm{~kg} / \mathrm{cm}^{2}\right)$ and moisture content $(14.3 \%)$ was observed in fruits stored for 18 days of storage interval. On the basis of findings it is recommended that persimmon fruits should be treated to reduce weight loss, fruit decay incidence, and maintain the firmness and TSS for more than 18 days of storage intervals.

Keywords: Coating; Corn oil; Storage; Persimmon

\section{Introduction}

The persimmon (Diospyros kaki) is a deciduous tree that originated in China and very popular in the Far East, Japan, South Korea and China [1]. It is commercially grown in China, Japan, Brazil, Italy, Spain, USA, New Zealand, Australia, Chile, Georgia, Iran, Israel and South Africa [2]. [3] the persimmon (Diospyros kaki) is a fruit of Japanese origin [4] was introduced in NWFP of Pakistan in 1940. The tropical agro climatic conditions of this province are well suited to this fruit. The commercially grown variety is astringent in nature. The major production areas include Peshawar, Mardan, Malakand, Dir. and Swat fruit Valleys [5]. The fair source of ascorbic acid and sugar and the sugars are present in the form of glucose and fructose [4]. Besides this, it also contains several carotenoid and other pigments. These fruits vary in size from 1.5 to $9 \mathrm{~cm}$ ( 0.5 to 4 in) diameter and 
come in different shapes like spherical, acorn or pumpkin. Persimmon (Diosypros kaki) is a good source of natural antioxidant, vitamins c, and dietary fiber which are probably involved in the reduction of degenerative human diseases [6] due to their anti-oxidative and free radical scavenging properties. The nutritional assessment of fruit had shown it to be good source of ascorbic acid, mineral, fibers and carotenoids [7]. Several researchers have reported the potential health benefits of persimmon due to its high antioxidant properties. Studies show that persimmons possess antitumor and multidrug resistance reversal properties [8], antidiabetic effects [9], hypochole sterolemic and antioxidant effects [10], and prevent the rise in plasma lipids [7]. As in the case in other climacteric fruit [11], ripening in persimmon is associated with a loss of firmness, changes in pigment content, and increase in total soluble solid (TSS) concentration. Persimmon vinegar also exhibits antitumor effects [12] and prevents metabolic disorders induced by chronic alcohol administration [13]. Two flavonolglucosides, isolated from persimmon have been shown to have a hypotensive action in rats [14]. Persimmon is very susceptible to physiological damage, particularly skin and flesh discoloration during storage. These injuries may be related to field factors and low storage temperature [15]. Persimmon generally has limited storability and a short shelf life. Fuyu persimmon can only be stored for 2 months under regular air storage at 0 to $2^{\circ} \mathrm{C}$ and $90 \%$ relative humidity [16] while Triumph persimmon stored for 4 months in modified atmosphere packaging (low density polyethylene bags)at $-1^{\circ} \mathrm{C}$ maintained adequate firmness, but accumulation of acetaldehyde caused fleshed browning. Postharvest losses in fruits and corns range 25-40\% [17]. [18] these losses bring low return to grower, processor, and traders and country also suffers in terms of foreign exchange earnings. However, the primary objective of research and development activities on postharvest handling and quality preservation of corns and fruits being carried out in the country is our national food security of to promote export of these high value commodities to other countries. In order to minimize these postharvest losses the coating techniques are used for fruits and corns. Different coating materials are used for this purpose.

\section{Materials and methods}

The research entitled "effect of coating material on the shelf life of persimmon" was conducted at post-harvest horticulture laboratory, the University of Agriculture Peshawar.

\section{Selection and harvesting of fruits}

Persimmons (Hachiya) fruits were harvested at mature light yellow (unripe) stage from newly development Research Farm, The University of Agriculture Peshawar KP, Pakistan.

\section{Transportation}

Persimmon fruit were carefully transported to post-harvest horticulture lab in wooden boxes.

\section{Cleaning and rouging}

Evaluations for physical properties were carried out in Horticulture Lab, The University of Agriculture Peshawar KPK. Defective fruits including wounded and other disorders were excluded. Fruits were washed with running tap water. Fruits were kept in storage room at ambient temperature $\left(21{ }^{\circ} \mathrm{C}\right)$.

\section{Selection and analysis}

Fresh fruits were tested for their weight loss (g), firmness $(\mathrm{kg} / \mathrm{cm} 2)$ and shelf life.

\section{Treatment application and storage}

The fruits were coated with oil and stored for a period of 20 days. Coating was made using one coating material i.e., corn oil 
along with control (without coating).These fruits were assessed three times with an interval of 3 days, for their weight $(\mathrm{g})$, firmness $\left(\mathrm{kg} / \mathrm{cm}^{2}\right)$ and shelf life.

\section{Experimental design}

The experiment was laid in completely randomize Design (CRD) with two factors i.e. coating material (With and without Corn Oil) and days to intervals $(0,3,6,9,12,15$ and 18), repeated three times during the experiment. The following parameters were studied during experiment:

\section{Weight loss (\%)}

Weight loss was measured with the help of digital weight balance. Fruit weight was recorded and then percentage of weight loss was calculated according to the following formula:

Fruit weight $l o s s \%=\frac{\text { initial reading }- \text { final reading }}{\text { initial reading }} \times 100$

\section{Fruit firmness $\left(\mathrm{kgcm}^{-2}\right)$}

Firmness was determined using penetrometer (Effigies, FT-011). Fruit surface was peeled with the help of blade, set the penetrometer on zero error, then pushing the penetrometer on the peeled surface, and note the reading in unit $\mathrm{kg} / \mathrm{cm}^{2}$. After each three days interval, three fruits were randomly selected from each lot and their firmness was determined by pressing the knob of the penetrometer into the fruit. The average of these three was the firmness of the whole lot.

\section{TSS ( ${ }^{0}$ Brix)}

Total soluble solid was estimated with a handhold refractometer at each interval of storage (Zeiss, ATAGO model NAR-3T, Japan).

\section{Moisture content (\%)}

Moisture content was determined by drying to constant weight at $60^{\circ} \mathrm{C}$ in a vacuum oven at $10 \mathrm{kPa}$ for $72 \mathrm{~h}$ (adaptation of method 934.06 AOAC, 2000). The percentage of the moisture content was calculated according to the formula.

Moisture content $(\%)=\frac{\text { fresh weight-dry weight }}{\text { fresh weight }} \times 100$

Table 1. Fruits deacy, TSS, Firmness, Weight loss and moisture contents affected by storage intervals and coating materials.

\begin{tabular}{|c|c|c|c|c|c|}
\hline & & & Parameter & & \\
\hline Coating & $\begin{array}{c}\text { Friut decay } \\
(\%)\end{array}$ & TSS (0Brix) & Firmness & $\begin{array}{c}\text { Weight loss } \\
(\%)\end{array}$ & $\begin{array}{l}\text { Moisture } \\
\text { content }\end{array}$ \\
\hline Corn Oil & $14.9 \mathrm{~b}$ & $20.9 \mathrm{a}$ & $2.5 \mathrm{a}$ & $6.4 \mathrm{~b}$ & $18.2 \mathrm{a}$ \\
\hline Control & $25.8 \mathrm{a}$ & $20.4 \mathrm{~b}$ & $2.4 \mathrm{~b}$ & $7.3 \mathrm{a}$ & $17.3 \mathrm{~b}$ \\
\hline $\operatorname{LSD}_{(0.05)}$ & 0.44 & 0.44 & 0.34 & 1.17 & 0.69 \\
\hline Storage in & (Days) & & & & \\
\hline $\mathbf{0}$ & $0 \mathrm{~g}$ & $16.8 \mathrm{f}$ & $3.3 \mathrm{a}$ & $0 \mathrm{f}$ & $22.4 \mathrm{a}$ \\
\hline 3 & $4.8 \mathrm{f}$ & $18 \mathrm{e}$ & $3 a$ & $1.3 \mathrm{e}$ & $21.4 \mathrm{a}$ \\
\hline 6 & $7.3 \mathrm{e}$ & $18.9 \mathrm{~d}$ & $2.8 \mathrm{a}$ & $4.1 \mathrm{e}$ & $19.8 \mathrm{~b}$ \\
\hline 9 & $16.5 \mathrm{~d}$ & $20.3 \mathrm{c}$ & $2.6 \mathrm{ab}$ & $6.1 \mathrm{~d}$ & $18.4 \mathrm{~b}$ \\
\hline 12 & $25.3 c$ & $22.4 \mathrm{~b}$ & $2.4 \mathrm{ab}$ & $8.1 \mathrm{c}$ & $16 \mathrm{c}$ \\
\hline 15 & $37.4 \mathrm{~b}$ & $23.7 \mathrm{a}$ & $2.1 \mathrm{~b}$ & $12.7 \mathrm{a}$ & $14.3 \mathrm{~d}$ \\
\hline 18 & $57.6 \mathrm{a}$ & $24.4 \mathrm{a}$ & $1.3 \mathrm{c}$ & $15.6 \mathrm{~b}$ & $12.2 \mathrm{e}$ \\
\hline $\operatorname{LSD}_{(0.05)}$ & 0.62 & 0.87 & 0.5 & 1.65 & 0.98 \\
\hline Interactio & & & & & \\
\hline $\operatorname{LSD}_{(0.05)}$ & ns & ns & $\mathrm{ns}$ & ns & $\mathrm{ns}$ \\
\hline
\end{tabular}




\section{Decay incidence $(\%)$}

Decay percentage find out on the following formula:

Decay incidence $(\%)=\frac{\text { No.offruits decayed }}{\text { Total No.of fruits }} \times 100$

\section{Results}

The fruits coated with corn oil showed that maximum fruit firmness $\left(2.51 \mathrm{Kg} / \mathrm{cm}^{2}\right)$, TSS $\left(20.92^{\circ}\right.$ Brix),lowest weight loss $(6.41 \%)$ and decay incidence (14.99\%). Whereas the minimum fruit firmness $\left(2.46 \mathrm{~kg} / \mathrm{cm}^{2}\right)$ and TSS (20.41 $\left.{ }^{\circ} \mathrm{Brix}\right)$, maximum weight loss (7.31\%) and decay incidence $(25.89 \%)$ was observed in uncoated (control) Fruits. In case of storage duration maximum weight loss $(15.65 \%)$, decay incidence (51.6\%), TSS $\left(24.48^{\circ} \mathrm{Brix}\right)$, minimum fruit firmness $\left(1.72 \mathrm{~kg} / \mathrm{cm}^{2}\right)$ and moisture content $(14.3 \%)$ was observed in fruits stored for 18 days of storage interval. While the lowest weight loss $(1.35 \%)$, decay incidence $(4.83 \%)$, TSS $\left(18.06^{0} \mathrm{Brix}\right)$, highest firmness $\left(3.03 \mathrm{Kg} / \mathrm{cm}^{2}\right)$ and moisture content (21.45\%) was observed at 3 days of storage intervals.

\section{Discussion}

Antifungal appearance [12] and antimicrobial activities higher when the respiration is higher and loss of sugar [13]. During the storage duration fruits decay reduces in initial days of fresh commodities and having all the physiological attributes are more in the fruits. Disruption and death of the microbial cells decay of fruits faster [14]. [15] found that, chinitin contents of cell wall reduce loss of fruits from fungal infection. Similar studied were observed by $[16,17]$ that pathogenic microorganisms were restricted when mango fruits were coated.. The storage life of persimmon fruits might be increased if the fruits are higher in calcium concentration in the plants storage life increase after removing from plants and store for later use. Loss of water from the surface of fruits, cell wall degradation, rapid respiration and ethylene concentration results to weight loss of fruits [17]. Storage of persimmon fruits period increase with increased in Cumulative Physiological Loss in Weight (CPLW). It might be due to increase in ethylene, respiration and loss of moisture from the surface of fruits cause significant loss in fruit weight of persimmon. Weight loss decrease regularly having direct effect on moisture content. Increase in weight loss, reduced metabolic activity and moisture loss from skin of the fruits [18]. Moisture levels totally depend on storage temperature and water pressure gradient between the fruit tissue and the surrounding atmosphere [19]. Softening of the fruits, loss of color, physiological changes, ethylene production and ripening process the fruits cause firmness [20]. Degree of methylation varied firmness from green and rife fruits mainly due to protein polymers [21], calcium which maintain adjacent chains bonded among themselves, also glycoside chains interconnected among themselves by phenolic compounds [22]. Hydrolytic enzyme activation due to ripening increased firmness that promotes intense solubilization of pectin present in the cell wall, mainly pectin methyl esterase (PME) and polygalacuronases (PG). High esterase activities in the cell wall of persimmon kernel suggest that rapid decrease in firmness [23-24]. It might be due to in the initial stages firmness more and ripening increase with decrease the firmness of persimmon fruit if storage time increased.

\section{Conclusions and recommendation}

Corn oil significantly affected all the studied parameters. Hence, it is recommended that corn oil increased the storage life of persimmon fruits.

\section{Authors' contributions}

Conceived and designed the experiments: $\mathrm{N}$ Alam \& F Bibi, Performed the experiments: N Alam, J Iqbal \& A Ahmed, Analyzed the data: SAS Bacha \& N Khan Contributed reagents/materials/ analysis tools: S Rawan, S Shah \& A Khan, Wrote the paper: N Ahmad \& BT Khan. 


\section{References}

1. Ahmed M (1979).Effect of waxing and lining materials on storage life of some citrus fruits. Froc Stats Hort Soc 92:237-240.

2. Amarante C \& Banks NH (2001). Postharvest physiology and quality of coated fruits and corns. Horti reviews 26: 161-238.

3. ASTM (1983).Standard test methods for water vapor transmission of materials. E 96-80. In Annual Book of American Standard Testing Method, ASTM: Philadelphia, PA.

4. AKRSP (1997). For Pakistan the production and marketing of fresh and dried fruits processing in different parts of Gilgit Baltistan.

5. Baj j, Alleyne RDH, Agenmaier JP, Mattheis \& Baldwin (2003). Foundation of zein coatings for Apple (Malus domestica bork). Postharvest Biol Technol 28(2): 259-268.

6.Baldwin EA (1994). Edible coating for fresh fruits and corns: past, present and future. In Edible Coating and Films to Improve Food Quality. (Edited by J. M. Krochta E.A. Baldwin \& M. O. Nisperos-Carriedo). Pp.25-64. Lancaster, Basel: Technomic Publ Co.

7.Dongowski (1994). Described the details of persimmon medicinal properties fruits, results analyzed for vitamin C 94(2): 274-279.

8.Anonymous (1973). Persimmon, Diospyrosvirginiana. Morton Arbor Quart 9:14-15.

9.Khan D, Khan AR, Bibi S, Ali S \& Khalil IA (2007). Storage stability of persimmon fruits (Diospyros Kaki) stored in different packaging materials. Department of Food Science and Technology, NWFP Agricultural University.

10. Khan R \& Jan T (1980). Planting and management of persimmon orchards in
NWFP. Dep. of Agric. Agric Res Inst Tarnab, Farmer's Bulletin No. 2.

11. Bill M (2012). Advancing harvesting maturity and improving storability of 'Triumph' persimmons. MSc Agric Thesis, Department of Horticultural Science, Faculty of Agri Science, Stellenbosch University.

12. Collins RJ, George AP \& Mowat AD (1993). The world trade in persimmon. [online].http://www.hortnet.co.nz/publ icactions/science/pers15.htm

(Accessed: 2012, $\quad$ August 09.

13. Mowat AD \& Chee AA (2011). Persimmon quality in New Zealand orchards. [online] htt://www.hortnet.co.nz/publications/s cience/pers6.htm (Accessed: 2012, May 17.

14. Kitagawa H \& Glucina PG (1984). Persimmon culture in New Zealand. New Zealand Department of Scientific and Industrial Research, Information Series 159.

15. Beede RH (1983). The storage performance of the Fuyu persimmon and its susceptibility to chilling injury. Msc. Thesis, Department of Pomology, University of California, Davis.

16. Collins RJ \& Tisdell JS (1995). The influence of storage time and temperature on chilling injury in Fuyu and Suruga persimmon (Diospyros khaki L.) grown in subtropical Australia. Postharvest Biology \& Technology 6:149-157.

17. Glucina PG (1987). Calyx separation: a physiological disorder of persimmons. Orchardist of New Zealand 60:161163.

18. Ito S (1971). The persimmon. Pp. 281301, In: Hulme, A.C. (Ed.). The biochemistry of fruits and their products. Academic Press New York, $N Y$. 
19. Ito S (1980). Persimmon. Pp. 442-468, In: Nagy, S. and P.E. Shaw (Ed.). Tropical and subtropical fruits, compositions, properties and uses. AVI Publ Co Westport, CT.

20. Kitagawa H \& Glucina PG (1984). Persimmon culture in New Zealand. N.Z. Dept Sci Ind Res Info Ser No. 159, Chapters 6 and 7.

21. MacRae EA (1987). Development of chilling injury in New Zealand grown Fuyupersimmon during storage. N.Z.J. Exp Agric 15: 333-344.

22. Prusky DR, Ben-Arie \& GuelfatR (1981). Etiology and histology of
Alternaria rot of persimmon fruits. Phytopathology 71: 1124-1128.

23. khan N, Shah N, Bibi F, Zeb S, Khan M, Iqbal J, Ghafoor F, Rawan S, Ahmad T, Ullah F, Faisal S \& Anwar U (2016). Post-harvest life of Persimmon (diospyros kaki $\quad$ L.) as affected by coating materials and storage intervals. Pure Appl Biol 5(4): 963-970.

24. Gul G, Ahmad N, khan N, Iqbal J, Ahmed A, Bacha SAH, Shah S, Ahmad S \& Khan A (2016). Quality of date palm cultivars response to storage at different days intervals. Pure Appl. Biol. 5(4): 1193-1199. 